\title{
EUMEU E AUERBACH: OS EFEITOS DA NARRATIVA EM HOMERO ${ }^{1}$
}

\section{Christian Werner* * Universidade de São Paulo.}

\begin{abstract}
RESUMO: Por meio de dois episódios na Odisseia, a reação de Eumeu às narrativas de Odisseu disfarçado como cretense no canto XIV e sua avaliação da performance do cretense em uma conversa com Penélope no canto XVII, esse artigo, iniciando-se por uma reavaliação do capítulo de Auerbach sobre a Odisseia em seu Mimesis, discute como alguns elementos de uma performance narrativa intradiegética são conceitualizados e explorados no poema.
\end{abstract}

PALAVRAS-CHAVE: Homero; Odisseia; performance; narrativa; Auerbach; Eumeu.

EUMAIOS AND AUERBACH:

THE EFFECTS OF THE NARRATIVE IN HOMER

ABSTRACT: By means of two episodes in the Odyssey, Eumaios' reaction to the narratives of Odysseus disguised as a Cretan, in Book 14, and his evaluation of the Cretan's performance when Eumaios is asked to bring the foreigner to Penelope, in Book 17, this paper, starting with a revaluation of Auerbach's chapter on the Odyssey in his Mimesis, discusses how some elements of a intradiegetical narrative performance are conceptualized and explored in the poem.

KEYWORDS: Homer; Odyssey; performance; narrative; E. Auerbach; Eumaios.

\begin{abstract}
Joana Xaviel demonstrava uma dureza por dentro, uma inclinação brava. Quando garrava a falar as estórias, desde o alumêio da lamparina, a gente recebia um desavisado de ilusão, ela se remoçando beleza, aos repentes, um endemônio de jeito por formosura. (...) Pegava a contar estórias - gerava tôrto encanto.
\end{abstract}

(J. Guimarães Rosa, “Uma estória de amor”)

\footnotetext{
${ }^{1}$ O presente trabalho foi realizado com apoio do CNPq. Agradeço a Antonio Orlando Dourado-Lopes, Teodoro R. Assunção, Jim Marks, José C. Baracat Júnior e ao público da XI Semana de Pós-Graduação em Estudos Clássicos: Reinterpretando Homero - UFMG (8-9/11/2012).
} 
$\mathrm{P}$ roponho desenvolver aqui, a partir de dois episódios da Odisseia de Homero, duas questões interligadas no âmbito da performance de uma narrativa: o condicionamento de certos modos da narração pelas condições de performance da poesia oral homérica; a representação de ouvintes intradiegéticos ${ }^{2}$ de uma narrativa na Odisseia, ou seja, formas de "conceitualização da reação dos ouvintes à poesia homérica". ${ }^{3}$ A conexão proposta pretende não só avançar a discussão acerca de como, na tradição épica grega, as variáveis implicadas na performance de uma narrativa intradiegética são exploradas nos próprios poemas, mas também discutir como se dá - ou pode-se dar - a comunicação, com o receptor extradiegético, das diferentes vozes mimetizadas pelo aedo na performance do poema, ou seja, grosso modo, a de Homero e as das personagens que enunciam discursos. ${ }^{4}$

\section{O Homero (bem alemão) de Auerbach}

Desde a primeira edição em alemão de Mimesis, de Erich Auerbach, a interpretação dada à poética homérica causou forte reação negativa entre filólogos da Antiguidade clássica. ${ }^{5}$ Ela foi lida ao pé da letra e se tornou, todavia, uma concepção hegemônica entre não especialistas. Auerbach defende que, em Homero, não haveria uma tensão entre diferentes planos da narrativa, pois, na interação entre o aedo e seu receptor, só valeria o primeiro plano, o presente permanente e absoluto. ${ }^{6}$ Nesse modelo, as partes discretas da narrativa, objeto único da atenção do receptor, destacam-se em relação ao todo e/ou a outras partes. Assim, esse modelo, segundo Michael Lynn-George, exigiria do leitor o esquecimento, de sorte que "o agora é sempre o todo - e o todo é sempre agora".

O próprio Auerbach, porém, nos "epilegomena" escritos para a tradução em inglês de 1953, alerta para aquilo que seus críticos não perceberam (e a que continuaram a não dar a devida importância): "I expected that the most serious objections against the train of thought in the book would come from the direction of classical philology, for ancient literature is treated in my book above all as a counterexample" (grifo meu). Quanto a Homero, diz o autor na sequência: "Here I have to admit, first of all, that the themes of Homer's

\footnotetext{
${ }^{2}$ Uso "intradiegético" em referência a algo que ocorre no interior da narrativa; "extradiegético" diz respeito à comunicação com o público externo à narrativa.

${ }^{3}$ Cf. Peponi, 2012, p. 56.

4 "Homero", aqui, não é um autor de carne e osso, mas a figura sempre pressuposta na recepção dos poemas. Concordo com Whitmarsh, 2009, que critica a figura narratológica do "narrador", inadequada para a compreensão da recepção de textos poéticos canônicos na Antiguidade.

${ }^{5}$ Nessa seção, para a contextualização de Mimesis, sobretudo de seu primeiro capítulo, sigo bastante de perto Porter, 2008; para uma versão resumida, cf. o verbete "Auerbach, Erich" feito por ele para Finkelberg, 2011.

${ }^{6}$ Cf. Auerbach, 1976, p. 1-20. Para uma recepção positiva recente do modelo de Auerbach, embora com diversas restrições, cf. Bakker, 2005, passim.

${ }^{7}$ Cf. Lynn-George, 1988, p. 12.

${ }^{8}$ Cf. Auerbach, 2003, p. 559.
} 
lack of tension and 'foregrounding' were emphasized all too strongly in the initial chapter, and that I am on the whole not entirely satisfied with my first chapter" (p. 560; grifo meu). Homeristas, porém, continuaram a criticar o autor ${ }^{9}$ sem levar em conta certos pressupostos do livro, no que talvez tenham sido motivados pelo sucesso que o modelo de história literária que oferece adquiriu nos estudos literários. ${ }^{10}$

A contextualização crítica de Auerbach e de seu livro mais conhecido feita por James Porter é certeira no que diz respeito ao capítulo sobre a cicatriz de Odisseu: da mesma forma que o amparo na lenda efetuada pela propaganda do regime nazista, Homero é pura simplicidade e superfície, ambos, portanto, tendo vínculos com a tradição classicizante na Alemanha moderna. ${ }^{11}$ Auerbach contrapõe, portanto, um clichê a outro, o grego (familiar) e o judeu (o outro radical).

Em que pese a análise cultural de Porter, defenderei que o modelo interpretativo de Auerbach está implícito em um dos modos de recepção de uma narrativa representados em Homero. Assim, ainda que o Homero de Auerbach seja fruto de uma deformação proposital e/ou ideologicamente motivada, isso não significa que não possa ser útil para se pensar a recepção antiga de Homero e sua própria conceitualização nos poemas. Como veremos, personagens de Homero não discordariam de Auerbach quando esse afirma que os poemas homéricos nos querem enfeitiçar e cativar: "a alegria pela existência sensível é tudo para eles (sc. os poemas homéricos)... para que observemos os heróis na sua maneira bem própria de viver e, com isto, nos alegremos ao vê-los gozando o seu presente saboroso, bem inserido em costumes, paisagens e necessidades quotidianas. E eles nos encantam e cativam de tal maneira que realmente compartilhamos o seu viver". ${ }^{12}$

"Encantar" (em alemão, "bezaubern") ${ }^{13}$ é mencionado na Odisseia como um efeito possível da poesia ou de um discurso que se assemelha ao canto poético. Antes, porém, vejamos como o próprio poema tematiza o caso de ouvintes que não se deixam encantar. Para isso, examinarei o uso de um recurso narrativo que chamo de "discrepância narrativa interna".

\section{DisCREPÂNCIA NARRATIVA INTERNA}

Defino discrepância narrativa interna ${ }^{14}$ como uma tensão gerada entre dois instantes distintos de uma narrativa épica sempre que 1) ambos referirem-se ao mesmo evento, 2) forem narrados por vozes distintas, ${ }^{15}$ o primeiro pelo poeta, o segundo, pela voz de uma

\footnotetext{
${ }^{9} \mathrm{~V}$. g. Austin, 1966.

${ }^{10}$ Cf., por ex., no contexto americano, Schein, 2007, p. 281.

${ }^{11}$ Cf. Porter, 2008, p. 118-127.

${ }^{12}$ Cf. Auerbach, 1976, p. 10, grifo meu.

${ }^{13}$ Cf. Auerbach, 1964, p. 13.

${ }^{14}$ Para uma defesa mais documentada dessa noção, cf. Werner, 2013, p. 83-104.

${ }^{15}$ Acerca da importância de se considerar a "voz" que emite um certo discurso em Homero, a distinção fundamental sendo aquela entre Homero e as personagens; cf. Bakker, 2009, p. 117-136. O autor
} 
personagem, ${ }^{16}$ e 3) o evento, tal como narrado pela personagem, estiver em desacordo com elementos significativos do evento tal como narrado por Homero. A discrepância é "interna”, pois a personagem que narra esteve presente no evento como partícipe ou espectador.

As discrepâncias que me interessam são aquelas que o próprio Homero não soluciona, ou seja, ele não alerta o receptor de que se trata de uma discrepância. Assim, à guisa de contraexemplo, Homero, antes de Odisseu dirigir seu segundo discurso ao jovem que ele não sabe tratar-se da deusa Atena, explicita que o receptor ouvirá uma mentira (Odisseia, XIII, 250-255). ${ }^{17}$ Homero, porém, não procede assim no canto XIV, quando Odisseu desenvolve sua persona cretense diante de Eumeu por meio de duas histórias, uma delas, sua biografia. Embora a falsa identidade assumida por Odisseu no canto XIII condicione o modo como seus discursos são percebidos pelo receptor extradiegético ao longo da segunda metade da Odisseia, pelo menos um deles, no canto XIV, parece compor um caso especial, como se verá adiante.

Um exemplo de uma intervenção de Homero depois de um discurso em desacordo com algo narrado antes é o comentário feito ao modo como Alcínoo entende o pedido de Nausícaa por um carro para ir lavar roupa (Odisseia, VI, 1-70): ao passo que a princesa forja uma motivação para o pedido e nada fala daquela que fora inoculada por Atena - suas bodas próximas -, Homero nos informa que o motivo central é percebido por Alcinoo (v. 66-67).

Essas passagens, porém, não levam à generalização de que Homero nunca deixa a seus receptores tal tipo de raciocínio e ele mesmo - ou suas personagens - os explicitam. ${ }^{18}$ Veja-se que a narrativa é plena de desníveis de conhecimento entre as personagens; ${ }^{19}$ de fato, na Odisseia, em vista da história que é contada, isso é onipresente. Além disso, faz parte da tática de sobrevivência de Odisseu, como bem demonstra a vitória (parcial) sobre Polifemo, a manipulação da linguagem. Que essa manipulação com frequência é óbvia para os receptores extradiegéticos, como, por exemplo, quando Odisseu afirma que seu nome é "Ninguém", não significa que, sempre que se tratar de uma distorção óbvia, o narrador nada informa, e

diferencia seu modelo do da narratologia stricto sensu, que propõe uma distinção puramente textual entre narrador-focalizador primário e secundário. Cf. também Bakker, 2013.

${ }^{16}$ É possível que a personagem, no segundo instante, refira-se a algo que ela mesma disse no primeiro instante; a referência, porém, é, via de regra, ao evento como um todo, não única e exclusivamente a uma fala sua.

${ }^{17}$ O texto da Odisseia usado é o de van Thiel, 1991.

${ }^{18}$ Um corolário da seguinte afirmação de Auerbach, 1976, p. 4: “impulso fundamental do estilo homérico: representar os fenômenos acabadamente, palpáveis e visíveis em todas as suas partes, claramente definidos em suas relações espaciais e temporais”. Não é por acaso, portanto, que leituras descontextualizadas de Auerbach tenham criticado essa interpretação. Assim, a épica homérica, segundo Lynn-George na sua crítica ao filólogo alemão, é uma forma que "nem esconde nem simplesmente revela", ou seja, nem sempre, como pressuposto por Auerbach, o que precisa ser dito é dito quando precisa ser dito (cf. Lynn-George, op. cit., p. 25-27).

${ }^{19}$ Bonifazi, 2012, p. 74, fala em "discrepancy of knowledge between the characters themselves, which enriches the negotiation of meaning". 
quando o narrador nada informar e a distorção for sutil, então não se trata de uma distorção, mas de característica de uma narrativa oral que, por definição, não apresentaria o mesmo tipo de coerência que se espera de uma narrativa feita para ser lida.

Homero às vezes explicita que uma personagem pensou uma coisa, mas disse outra (Odisseia, XIX, 203; XXI, 96-97), mas outras vezes não. Quando Odisseu, reagindo a uma crítica que Alcínoo faz à filha, mente dizendo que foi ele quem não quis entrar com Nausícaa na cidade, o narrador nada observa, ficando a cargo do receptor perceber que se trata de uma "mentira", ou seja, que ele teve razões para disfarçar o ocorrido (Odisseia, VII, 298-307).

Um caso mais sutil se dá na conversa entre Hermes e Calipso no canto V, quando o deus compõe uma versão do naufrágio de Odisseu cujo responsável seria Atena (v. 108110). Ato contínuo, Calipso corrige o deus e mostra que Zeus é o único responsável (v. 118-144). Também aqui, nem Calipso explicitamente corrige Hermes, nem Homero faz algum comentário. Todavia, o receptor que se colocar no lugar da ninfa percebe que Hermes manipulara a verdade para tornar mais fácil a tarefa incômoda de persuadir sua interlocutora a liberar Odisseu sem gerar discussões constrangedoras. Interessante, nesse exemplo, é que, do ponto de vista do ouvinte da Odisseia como um todo, o naufrágio de Odisseu ainda não foi narrado; ele só o será no canto VII e, seus antecedentes, no canto IX. Pode-se postular, claro, que Homero jogue com o conhecimento dos ouvintes, inclusive de versões do retorno de Odisseu que não se tornarão/-am canônicas, ${ }^{20}$ mas, como assinala Ruth Scodel, para uma narrativa funcionar, nem toda lacuna precisa ou deve ser preenchida, em especial, aquelas que dependem de conhecimento prévio do público. ${ }^{21}$

Não creio, portanto, que haja uma "lei" na narrativa épica arcaica segundo a qual toda informação necessária para um ouvinte compreender uma cena é explicitada pelo poeta. Talvez a passagem mais famosa que corrobore a eficácia da comunicação entre poeta e público também depender do que não é dito seja a recepção das almas dos pretendentes no Hades (Odisseia, XXIV, 1-202). Ao chegarem, a alma de Agamêmnon se espanta e pergunta ao pretendente que conhecia o que ocorreu. Esse lhe informa que Odisseu chegou disfarçado à sua casa e, graças a um plano que arquitetou com Penélope, todos os pretendentes foram mortos. Não só Homero não faz comentário algum acerca dessa visão equivocada dos fatos que ele próprio narrara, mas também nada comenta acerca da reação de Agamêmnon, um discurso de louvor do par Penélope e Odisseu ${ }^{22}$ baseado no equívoco que acabara de ouvir. A interpretação do equívoco e de sua relação com o discurso que ele gera depende do ouvinte, e isso não é irrelevante, pois em nenhuma outra passagem se elogia o heroísmo de Penélope e Odisseu em conjunto de forma tão contundente quanto aqui.

\footnotetext{
${ }^{20}$ Cf. a análise que Danek, 1998, faz de todo o poema utilizando esse viés.

${ }^{21}$ Cf. Scodel, 2004, p. 62-64.

${ }^{22}$ Discurso ambíguo, bem entendido; cf. Werner, 2001.
} 


\section{EUMEU E AS "MENTIRAS CRETENSES"}

No tipo de construção que me interessa, uma informação discrepante é dada por uma personagem sem que Homero, nem antes nem depois do discurso da personagem, sinalize ao receptor a discrepância que, por sua vez, pode ser, direta ou indiretamente, relevante para outra personagem em cena que também participou do evento contado anteriormente.

Inicio pela cena no canto XVII que envolve o pretendente Antínoo, Odisseu disfarçado de mendigo (passo a chamá-lo de Cretense sempre que essa identidade estiver em questão) e o porqueiro Eumeu; os dois últimos acabaram de chegar e entram no banquete no qual tomam parte os pretendentes e Telêmaco. O Cretense resume sua vida diante deles (Odisseia, XVII, 419-444), mas Eumeu, que já conhece uma outra versão dessa mesma história, pois Odisseu a contara duas noites antes (Odisseia, XIV, 192-359) ${ }^{23}$ não é explicitado pelo poeta como parte do público nesse momento da narrativa. Não se trata, portanto, apenas de discrepância entre dois discursos motivados por questões pragmáticas distintas. A presença de uma testemunha dos dois discursos permite uma comparação entre o segundo discurso e a cena como um todo da qual o primeiro discurso foi parte constituinte. Como veremos, a recepção do primeiro discurso por Eumeu se espraia pelo restante do canto XIV e pela cena em questão no canto XVII.

De forma resumida, o Cretense conta diante dos pretendentes que também já fora rico, mas se arruinou ao viajar para o Egito, pois não conseguiu controlar seus companheiros, e esses atacaram, de forma desatinada, os habitantes locais, que se reagruparam e derrotaram os invasores, que foram mortos ou escravizados. O Cretense, enviaram-no a Chipre como escravo, de onde acabou de chegar a Ítaca.

Entre as duas versões ouvidas por Eumeu, só há uma grande discrepância: o destino do Cretense após a derrota no Egito (Odisseia, XIV, 273-359). ${ }^{24}$ Na primeira versão, ele não é escravizado, mas cai nas boas graças do rei local, que o poupa, contrariando o restante do exército. Além disso, fica sete anos no Egito e acumula muitas riquezas, pois todos o honravam. Para o receptor extradiegético, essa diferença entre os cantos XIV e XVII aponta para dois modos de tratar um estranho, que se manifestam, de um lado, na hospitalidade de Eumeu oferecida nos cantos XIV-XVI e, de outro, na descortesia violenta dos pretendentes. Além disso, as duas representações do rei egípcio também se relacionam a um tema que perpassa todo o poema: a qualidade de um rei. Odisseu, como rei, foi forte, justo e gentil como um pai, algo reiterado ao longo da Odisseia. ${ }^{25}$

Por fim, na primeira história ouvida por Eumeu, o Cretense não é enviado a Chipre, mas decide deixar o Egito persuadido por um velhaco fenício. Da Fenícia, é coagido a

\footnotetext{
${ }^{23}$ Para uma leitura complementar da biografia fictícia contada por Odisseu a Eumeu, cf. Werner, Carpintaria de narrativas na Odisseia de Homero: Eumeu e o mendigo cretense. In: GALLE, H. (org.) Ficcionalidade: Abordagens de um fenômeno literário e seus contextos históricos. São Paulo, Ed.Unesp, no prelo. ${ }^{24}$ Cf. de Jong, 2001, ad Odisseia, XVII, 419-444.

${ }^{25}$ Cf. Olson, 1995, p. 184-204, para o retorno de Odisseu como o "retorno do rei"; cf. também Levaniouk, 2011, p. 50-56.
} 
viajar para a Líbia, intuindo que lá seria vendido como escravo. Ocorre um naufrágio e ele, sobrevivente, chega à terra dos tesprócios onde é bem recebido pelo rei e é informado do retorno iminente de Odisseu. Novamente, porém, cai nas mãos de navegadores inescrupulosos e, na costa de Ítaca, consegue fugir e se depara com a cabana de Eumeu.

$\mathrm{Na}$ versão bem mais curta da história que o Cretense conta para Antínoo, ele não menciona sua primeira grande aventura em Troia, quando ainda era um cidadão de respeito. Além disso, ao reduzir sua viagem posterior ao fracasso egípcio a uma estada em Chipre, não mencionando a Fenícia e a Tesprócia, toda essa edição e mudança realça, para quem ouviu a versão anterior - ou seja, nós, o público externo, $e$ Еumeu - a ausência da personagem Odisseu, onipresente nos relatos feitos pelo Cretense a Eumeu no canto XIV. O oposto disso, por assim dizer, aparece no diálogo posterior ao relato do Cretense diante dos pretendentes, aquele entre Eumeu e Penélope, ainda no canto XVII, quando o porqueiro superdimensiona a relação entre o Cretense e Odisseu e os chama de xeînoi, amigos-hóspedes (Odisseia, XVII, 522-523), algo que não foi dito pelo Cretense no canto XIV, mas o será posteriormente, só que então a Penélope (Odisseia, XIX, 185). ${ }^{26}$

O Cretense, ironicamente, aconselha Antínoo acerca do modo mais apropriado de ser tratado, ou seja, o contraponto com a hospitalidade de Eumeu, desconhecida para Antínoo, e se torna um dos principais pontos focais da cena, senão o principal. ${ }^{27}$ Por isso não surpreende que não seja reiterada, por Homero, a presença de Eumeu na cena, ele que já ouvira outra versão da mesma história e poderia estranhar a mencionada discrepância. ${ }^{28}$ Não devemos considerar, porém, que o mudo Eumeu suma da consciência do receptor do poema, não só porque em outras cenas envolvendo os autores principais do conflito Odisseu, Telêmaco e os pretendentes - a presença do porqueiro é relevante, mas sobretudo porque ele é parte fundamental no início da troca de falas que conduz à história contada pelo Cretense (Odisseia, XVII, 290-404).

De forma algo surpreendente, além disso, Eumeu retorna ao primeiro plano da narrativa quando, após o ataque físico de Antínoo contra o Cretense e a troca de ameaças entre eles (Odisseia, XVII, 405-491), Penélope manda chamar o porqueiro, e então, no diálogo que segue, o receptor percebe que a avaliação que Eumeu fizera do Cretense no canto XIV não é mais a mesma, pois lá o porqueiro ainda criticara o mendigo por conta de afirmações acerca do retorno iminente de Odisseu (Odisseia, XIV, 361-87). ${ }^{29}$

\footnotetext{
${ }^{26}$ A motivação do comentário de Eumeu foi interpretada de várias formas; cf. Stanford, 1965, ad Odisseia, XVII, 522 e de Jong, 2001, ad Odisseia, XVII, 522-527.

${ }^{27}$ Cf. Blümlein, 1971, p. 59-62 e Steinrück, 1992, p. 179.

${ }^{28}$ Eumeu e Antínoo, no papel de anfitriões, são antípodas que recebem narrativas correspondentes do Cretense que eles hospedam in/corretamente; acerca dessa "figure of the host who provokes

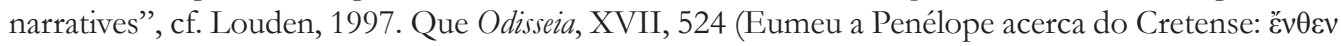

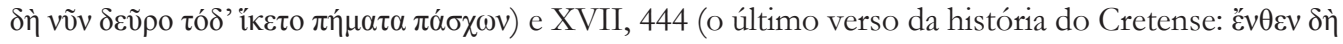

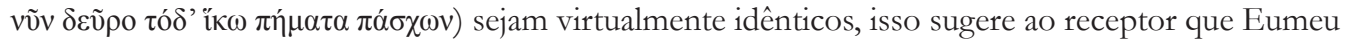
prestou cuidadosa atenção ao que o Cretense contara; cf. Blümlein, 1971, p. 58-59.

${ }^{29}$ Para uma discussão dos diálogos entre o Cretense e Eumeu, que complementa o exame a ser feito adiante, abordando as diferenças na recepção das duas narrativas do Cretense por parte do porqueiro,
} 
Eumeu fica emocionado com a história do Cretense (Odisseia, XIV, 361) e parece se identificar com seu hóspede por motivos que só ficarão claros ao receptor quando, no dia seguinte, contar-lhe sua história. Trata-se de eventos que Eumeu gostou de ouvir (v. 362:

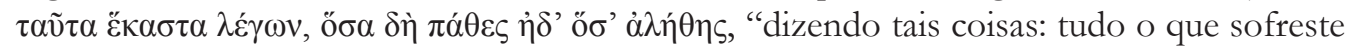
e viajaste!" $)^{30} \mathrm{e}$ considera verdadeiros.

O Cretense, porém, introduzira Odisseu como um quase epílogo da sua história, ao afirmar que teria ouvido de fonte segura que Odisseu estava em um reino vizinho preparandose para voltar a Ítaca. Essa parte da história desagrada muito ao porqueiro, pois já ouvira mentira equivalente, havia não muito tempo, de outro estrangeiro a quem deu hospedagem generosa (v. 378-385).

Para discutir-se o que está em jogo nesse duplo juízo, que é moral e estético, não basta perceber que a biografia fictícia inventada por Odisseu é, na sua maior parte, uma mentira ou ficção crível, pois composta por eventos interligados de forma verossímil e necessária, ao passo que a única verdade factual embutida na narrativa, o retorno iminente de Odisseu, é desacreditado por Eumeu, pois evoca um engodo do qual já foi vítima. O porqueiro pode apreciar o relato do estranho e, ao mesmo tempo, eliminar como falsa uma parte da narrativa ouvida.

Eumeu, para caracterizar o que ouviu, utiliza a expressão on katà kósmon (v. 363). Podemos considerá-la virtualmente um sinônimo de pseúdeis ("mentes"), sobretudo se aceitarmos que o verbo que fecha esse verso, peíseis, pode aludir fonicamente à forma pseúdeis, assim como o verbo que conclui o verso anterior, aléthés, remete a alètheiée (Odisseia, XIV, 361-366):

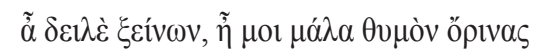

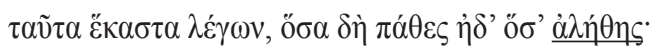

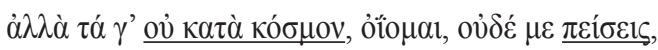

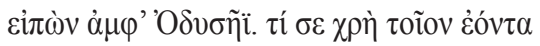

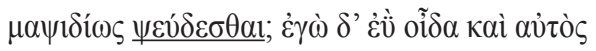

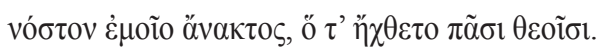

Ó pobre estrangeiro, na verdade me comoveste o coração,

dizendo tais coisas: tudo o que sofreste e viajaste!

Mas há uma parte que para mim não está certa, nem me poderás

convencer a respeito de Ulisses: que necessidades tens tu, na tua situação, de mentir em vão? Da minha parte sei bem, quanto ao regresso do meu amo, que é detestado por todos os deuses...

cf. Werner, Carpintaria de narrativas na Odisseia de Homero: Eumeu e o mendigo cretense. In: GALLE, H. (org.). Ficcionalidade: Abordagens de um fenômeno literário e seus contextos históricos. São Paulo, Ed.Unesp, no prelo.

${ }^{30}$ A repetição agradável dos sons $a, e, t(h)$ e $l$ reiteram fonicamente que se trata de algo do relato que o porqueiro gostou de ouvir. A tradução da Odisseia, aqui e abaixo, é de Frederico Lourenço, 2011. 
Kósmos, porém, no contexto da poesia hexamétrica arcaica, é um termo polissêmico, referindo-se a um tipo de adequação ou ordem que pode ser, inclusive concomitantemente, epistemológica, social/moral e estética. ${ }^{31}$ Ao optar pela expressão, Eumeu não limita o juízo que faz acerca do que ouviu a uma oposição entre verdade e mentira.

Ao compreender-se a avaliação de Eumeu em conjunto com outras manifestações suas nesse episódio, contudo, fica claro para o receptor que o porqueiro está acusando o estranho de mentiroso. A crítica ocorre porque Eumeu desconhece a verdade e não é persuadido por algo que sua experiência indica ser falso, ainda que em tensão com a emoção que o relato como um todo lhe causa.

O advérbio empregado para qualificar a ação de mentir, $\mu \alpha \psi 1 \delta$ í⿴\zh11 (v. 365), diz respeito a um certo excesso no âmbito moral ou cognitivo, ou seja, de forma geral, a uma falta de contenção ou de ordem, de correta avaliação do contexto. ${ }^{32}$ A crítica principal, portanto, não é necessariamente ao descompasso entre a narrativa do Cretense e a realidade de Eumeu, mas ao excesso desse descompasso. Eumeu desconhece por completo o estranho, por isso não tem condições objetivas de separar o que é falso daquilo que é verdadeiro no seu relato, e julgar que é isso que ele pretende fazer é ignorar o que significa apreciar uma história na Odisseia (e na poesia homérica de forma geral). O que Eumeu ouviu é criticado porque não foi bem composto pelo Cretense tendo em vista seu público, crítica que está em dissonância com o prazer que nós sentimos ao ouvir o longo, engenhoso e emocionante relato fictício. Isso reforça a indicação do prazer de Eumeu com a narrativa, o que lhe causa, por sua vez, dificuldade de julgar negativamente mesmo que só uma parte da história ouvida. ${ }^{33}$

Esse juízo de Eumeu é preparado de diversos modos na composição do canto XIV. Desde o início do encontro entre os dois homens, Eumeu faz o "desaparecido" Odisseu entrar na conversa; dele diz ter lutado em Troia, mas posteriormente ter desaparecido e provavelmente estar morto (Odisseia, XIV, 37-47 e 61-71). Não se trata de mera informação, porém; um contexto moral é explicitado, segundo o qual há pessoas de bem, que, por exemplo, honram os preceitos pelos quais Zeus zela (v. 56), e pessoas vis que ignoram os deuses (v. 81-84). O principal modo de opor esses grupos é através dos meios que empregam para obter ou produzir riqueza. O problema desse mundo é que nada garante que aqueles que são bons, como Odisseu, serão constantemente favorecidos pelos deuses. Com isso, a dificuldade é por que os deuses interromperam o retorno de Odisseu (v. 61). Apesar disso, no mundo de Eumeu, só merece consideração quem age com moderação e justiça.

Ao expor seu modo de entender o mundo e as ações humanas e divinas, Eumeu indica que vai tratar seu hóspede como gostaria que seu mestre, Odisseu, fosse tratado em terra estrangeira se ainda estivesse vivo. Em contrapartida, gostaria do mendigo que se

\footnotetext{
31 Acerca dos sentidos possíveis dessa expressão, cf. sobretudo Halliwell, 2011, p. 84-88 - com bibliografia - e Ford, 1992, p. 122.

${ }^{32}$ Cf. LfgrE s. v. $\mu \alpha \psi i ́ \delta$ ios 7, 310.

${ }_{33}$ Para conclusões semelhantes, ainda que não alcançadas por argumentação idêntica, cf. Halliwell, 2011, p. 47-53.
} 
comportasse como alguém que teme os deuses, pois até homens que estão em território estrangeiro para pilhar assim se comportam (v. 85-88).

O recado que Eumeu manda a seu hóspede, portanto, é duplo: 1) não há ninguém que ele honre mais que Odisseu; 2) está muito atento às ações daqueles com os quais interage, em particular, estrangeiros. No mundo de Eumeu, os pretendentes e Odisseu compõem dois polos morais. Assim, quando o Cretense sugere talvez possuir informações sobre Odisseu, não basta ele invocar o testemunho de Zeus (v. 115-120). A afirmação de que muito vagou

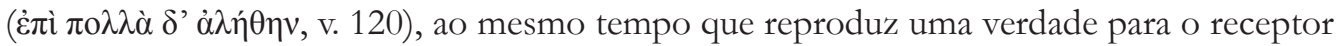
do poema, sugere, para Eumeu, sua falsidade. ${ }^{34}$ As semelhanças fônicas da forma verbal com o adjetivo alethès não são suficientes para conseguir que a história a ser narrada ultrapasse a barreira da experiência e das expectativas de Eumeu. Pelo contrário, em um poema no qual relatos mentirosos ou parcialmente verdadeiros notoriamente são introduzidos por declarações que afirmam a veracidade do que se vai falar, insistir na verdade pode sugerir ao interlocutor que ele tem todas as razões para duvidar do que vai ouvir.

Eumeu faz questão de indicar ao Cretense que sabe haver ouvintes distintos, entre os quais, como que a marcar dois polos, estão os ingênuos e crédulos, de um lado, e os céticos, de outro. Penélope, porém, parece estar como que entre esses dois polos (Odisseia, XIV, 122-132):

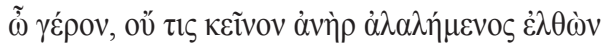

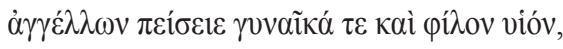

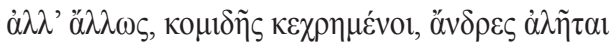

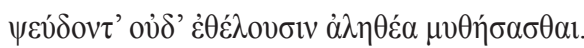

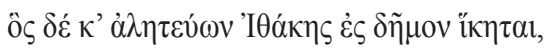

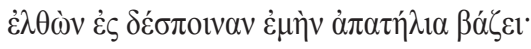

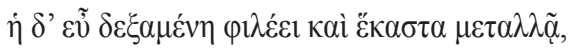

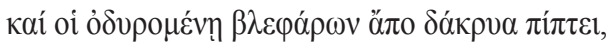

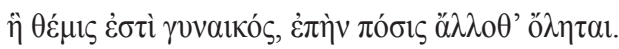

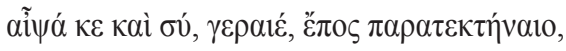

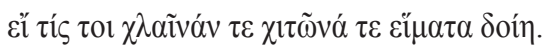

Ancião, nenhum viandante que aqui chegasse com notícias dele seria capaz de persuadir a mulher e o filho amado, pois de qualquer maneira os viandantes necessitados de comida mentem, sem qualquer vontade de dizer a verdade. Qualquer um que porventura chegue à terra de Ítaca vai logo contar à minha senhora uma história inventada. Ela recebe-o com gentileza e tudo lhe pergunta e, lamentando-se, das suas pálpebras caem lágrimas, como é próprio na mulher, quando lá longe lhe morreu o esposo.

${ }^{34}$ Segal, 1994, p. 164-185. 
Depressa tu, ó ancião, inventarias uma história, se alguém te oferecesse uma capa e uma túnica para vestires.

Embora desconfie da história, Penélope tem prazer em ouvi-la ${ }^{35}$ e presenteia seu autor, mesmo descrendo do relato. $O$ prazer de quem ouve parece ser suficiente para que o relato seja recompensado (v. 131-132), o que reforça que a presença de elementos percebidos mais agudamente como "falsos" por Eumeu na biografia do Cretense não eliminam o prazer que lhe causa a história como um todo.

Quanto a Odisseu, Eumeu é um ouvinte que, para honrar a memória de seu senhor, só reage bem a relatos elogiosos ou que sua experiência não analise como inverídicos. De fato, todo relato acerca de Odisseu é potencialmente problemático no presente, pois não se sabe nem mesmo onde ele está enterrado (v. 133-137, 367-371). A narrativa em torno de Odisseu construída por Eumeu tem tom e tópos de um lamento (v. 137-144), o único tipo de discurso que parece poder fixar uma imagem positiva que se coadune com a dor do porqueiro. Com isso, até o próprio nome de Odisseu é ressemantizado, ou melhor, como o nome remete a "ódio", emoção que caracteriza inimigos, Eumeu, no espaço do seu discurso de louvor, nem mesmo consegue mencionar o nome de seu dono (v. 145-147).

Resumindo, desde o início do encontro entre o porqueiro e o Cretense, Eumeu contrapõe a sua representação de Odisseu e do mundo ao conteúdo dos relatos que o estranho poderia fazer. Ao passo que Eumeu não quer ouvir uma falsa promessa, Penélope não parece se incomodar com esse tipo de relato. Com efeito, Eumeu, ao contrário de sua senhora, já se comportou certa vez como um ouvinte ingênuo e acreditou no que lhe contaram (v. 378-385), ou seja, foi enfeitiçado (v. 387: thélge).

\section{O Cretense em Troia}

Quando o Cretense afirma que o coração de Eumeu é sempre incrédulo (Odisseia, XIV, 149-150), ele parece fazer uma observação objetiva, mas, de fato, mostra a Eumeu uma imagem que esse tem de si mesmo na qual gostaria de acreditar. Quanto a relatos acerca de Odisseu, para Eumeu (mas não para Penélope e Telêmaco) só haveria duas modalidades possíveis: relatos verdadeiros, portanto, de louvor e/ ou de lamento, e relatos mentirosos que anunciam seu retorno, portanto, indignos de serem pronunciados. A recepção de Eumeu à segunda narrativa do Cretense revela, porém, que a apreciação crítica de uma história e o prazer que causa têm relações mais complexas que aquelas que Eumeu acredita estar em jogo no seu caso (v. 457-517).

O Cretense, para obter um manto de Eumeu, conta um episódio ocorrido em Troia no qual Odisseu, numa tocaia noturna, consegue, por meio da astúcia, obter um manto para o Cretense, que deixara o seu no acampamento (Odisseia, XIV, 464-502). Nem Homero, nem

\footnotetext{
${ }^{35}$ Peponi, 2012, p. 33-69, demonstra que, nos poemas homéricos, lágrimas, prazer estético e reflexão não são incompatíveis, ou seja, o distanciamento não é pensado como uma condição sine qua non; cf. também Halliwell, 2011, p. 36-92, sobretudo p. 77-92.
} 
o Cretense nem a reação do próprio Eumeu indicam qual o caráter de verdade da história. Ao contrário da biografia, a história não causa nenhuma dor no porqueiro, apenas prazer (v. 508-509), muito embora um manto seja o objeto que Eumeu escolheu para exemplificar as razões por que um estranho como o Cretense inventaria uma história diante de Penélope (v. 132). No episódio troiano, porém, o manto é o centro mesmo da história e do contexto de sua performance (v. 508-510):

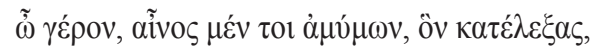

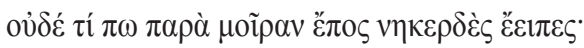

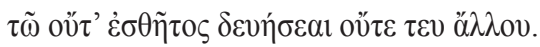

Ó ancião, é irrepreensível a história que contaste.

Não disseste palavra que estivesse fora do lugar ou fosse inútil.

Por isso não te faltará roupa ou qualquer outra coisa...

O contraste com o restante do canto XIV mostra que Eumeu não está interessado na veracidade dessa segunda história. O que a distingue é que não trata do retorno de Odisseu, ${ }^{36}$ e, além disso, sugere-se que, do ponto de vista de Eumeu, toda a história é construída como um elogio de Odisseu. Todavia, o sucesso de Odisseu é conseguido por meio de uma mentira (bem sucedida), justamente o resultado de um tipo de inteligência que Eumeu criticara anteriormente. Talvez seja essa a razão principal pela qual Eumeu não elogia a história e seu contador do modo como fará no canto XVII diante de Penélope, como veremos abaixo. Além disso, o entusiasmo de Eumeu é contido, pois ele faz questão de frisar que o empréstimo do manto é por apenas uma noite.

De qualquer forma, Eumeu considera a história adequada, ou seja, dessa vez, o Cretense compôs uma de forma a agradar seu público. Assim, que a história não reproduza um material tradicional como, por exemplo, o cavalo de Troia, me parece ser completamente irrelevante do ponto de vista do receptor extradiegético. O prazer causado pela história torna uma indagação sobre sua veracidade calcada em um conhecimento prévio, irrelevante.

\section{A performanCE DE UMA NARRATIVA COMO FEITIÇO}

Para Eumeu, no final do canto XIV, a imagem do Cretense é, portanto, a de um narrador eficiente, que sabe cultivar de forma adequada a imagem de Odisseu, mas em relação ao qual é necessário um mínimo de desconfiança, algo que, no universo da Odisseia, não é culturalmente negativo.

Daí, quando Penélope, no canto XVII, solicita de Eumeu uma entrevista com o Cretense, a forma como o porqueiro louva o estranho não é, necessariamente, elogiosa (Odisseia, XVII, 513-521):

\footnotetext{
${ }^{36}$ Não fala diretamente; toda tocaia só é bem sucedida, como a contada na história, quando os atacantes conseguem retornar.
} 


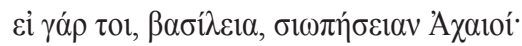

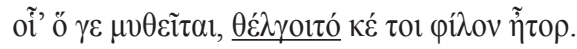

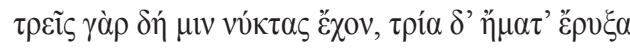

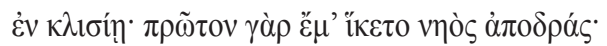

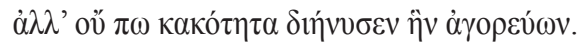

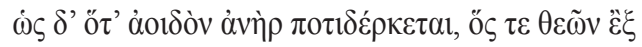

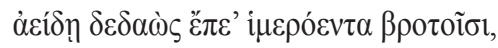

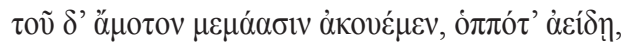

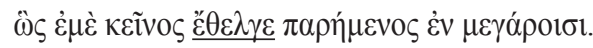

Quem me dera, ó rainha, que os Aqueus se calassem.

As coisas que ele diz! Enfeitiçará o teu querido coração.

Há três noites que ele está comigo; três dias passou comigo

no casebre, pois foi primeiro para junto de mim que chegou

quando fugiu da nau; mas não contou ainda as dores todas.

Ouvi-lo é olhar para um aedo, que para os mortais canta

palavras cheias de saudade, que os deuses lhe ensinaram,

e todos desejam ardentemente ouvi-lo cada vez que canta -

assim o estrangeiro me enfeitiçou, sentado no meu casebre.

Mesmo supondo-se que thélgein, o verbo traduzido acima por "enfeitiçar", possa ter, em certos contextos, um sentido ambíguo, ${ }^{37}$ e que essa ambiguidade se manifestaria na representação do aedo no símile, aedo que, em outras passagens odisseicas, talvez não seja avaliado ou caracterizado de forma inequivocamente positiva, ${ }^{38}$ há diversos elementos no discurso de Eumeu que delimitam o sentido de thélgein como o efeito de uma performance, ${ }^{39}$ em particular, os que sugerem uma performance poética ideal (sublinhados acima na tradução em português): o silêncio é marca da performance de um aedo ou de alguém que age como um (Odisseia, I, 325; XI, 333 = XIII,1); a performance que se alonga por um tempo que ultrapassa um certo padrão também é marca de qualidade (Odisseia, III, 103-117; IV, 240-243; IX, 13 15; XV, 390-402); quando o anfitrião se dá conta do potencial de entretenimento de seu hóspede, ele pode jactar-se disso junto a outros que se beneficiam desse mesmo hóspede

${ }^{37}$ Central, portanto, o episódio das Sirenas, as cantoras que agem como feiticeiras por excelência. Peponi, 2012, p. 76, defende que elas "seem to incarnate not an exclusive but an archetypal model of musical thelxis" e, mais adiante, que elas ocupam um lugar intermediário entre diferentes categorias (deuses e mortais, idílio e horror, monódia e canto coral, épica e lírica), de sorte que "this distinctive musical hybridity represents a distinctive aspect of the overall aesthetic model the Odyssean Sirens incarnate” (p. 80), qual seja, a fusão entre o sujeito da performance e o ouvinte (p. 94).

${ }^{38}$ Cf. Werner, 2005.

39 A argumentação abaixo foi desenvolvida de forma independente da leitura de Halliwell, 2011, p. 36-55, com a qual ela concorda no que diz respeito à necessidade de dar importância ao duplo uso de thélgein por Eumeu nos cantos XIV e XVII da Odisseia; minha interpretação, porém, é em larga medida distinta. 
(Odisseia, XI, 335-346); diz-se do cantor hiperbolicamente bom que ele recebeu um dom dos deuses (Odisseia, VIII, 477-481; XXII, 345-349); o bom cantor canta sem cessar, ou seja, não é interrompido pela sua plateia (Odisseia, VIII, 83-103).

Eumeu, todavia, dias antes em sua cabana, após ouvir a biografia do Cretense (mas antes do aînos), afirmara que não seria enfeitiçado (Odisseia, XIV, 387). A Penélope, porém, diz que fora enfeitiçado como se tivesse assistido a um cantor. $O$ narrador não comenta essa discrepância, e tampouco nós podemos ter certeza de que realmente se trata de uma. Contudo, o receptor extradiegético pode relacionar esse juízo com a recepção de Eumeu das duas histórias que ouviu do Cretense depois de jactar-se de ser imune aos feitiços, o aînos e a história narrada diante de Antínoo.

Já se defendeu que thélgein não é um efeito estético particular na Odisseia, distinto, portanto, em essência, de térpein, mas apenas o prazer próprio da música/poesia em grau máximo, ${ }^{40}$ e que esse efeito não é incompatível com algum tipo de reflexão concomitante à recepção do relato ou do canto. Nesse caso, em relação à passagem em questão, não haveria discrepância alguma, pois, como vimos, algum tipo de prazer e de reflexão se fazem presentes na recepção das duas histórias contadas no canto XIV.

Há algo de hiperbólico, porém, na avaliação que Eumeu faz diante de Penélope, de sorte que, se o ouvinte construir nem que seja a possibilidade de uma discrepância, essa pertence a um andamento narrativo no qual é reforçada a representação do Cretense como narrador de um certo tipo de história, uma biografia atualizada ou representada sob formas distintas. Essa representação refere-se ao modo como ele constrói suas narrativas e às situações de performance que enfrenta, em particular, ao modo como públicos distintos reagem a suas histórias e Homero dele fala. Tendo em vista que um aedo levaria em conta características particulares de públicos diversos para desenvolver suas performances, ${ }^{41}$ por meio da discrepância entre o comentário de Eumeu feito ao Cretense e aquele à Penélope sugere-se ao receptor que o porqueiro pode perceber no estranho um aedo por excelência sobretudo após ouvir uma sua terceira história. Eumeu, porém, pode também estar mentindo, ou seja, nunca ter sido enfeitiçado.

Há um elemento adicional que sustenta essa interpretação. Diante dos pretendentes e antes de o Cretense contar sua história, o porqueiro já indica, de forma oblíqua, que, para ele, o valor do mendigo assemelha-se ao de um cantor (Odisseia, XVII, 381-387):

\footnotetext{
${ }^{40}$ É a interpretação de Halliwell, 2011, que defende que, nos poemas homéricos, o canto produz "states of rapt concentration and engagement (...) a compelling grip on the mind" (p. 45), e termos como térpein "are stamped with strong associations of deep fulfillment or release; they often carry quasi-physical connotations even where thought or emotion is concerned" (p. 45). Assim, thélgein "characterizes at its highest, most intense pitch the condition of rapt absorption and (in the etymological sense) fascination which is a recurrent feature of Homeric images of song" (p. 47).

${ }^{41}$ Cf. Scodel, 2002 e 2004.
} 


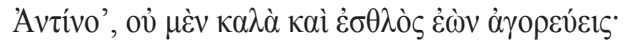

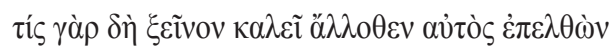

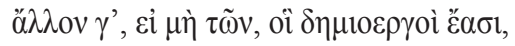

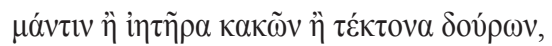

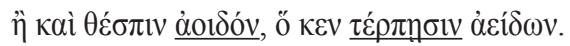

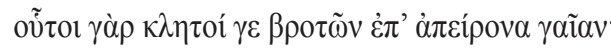

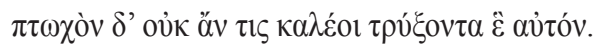

Antínoo, apesar de seres nobre, não são belas as tuas palavras.

Quem é que vai ele próprio chamar outro, um estrangeiro,

de outra terra, a não ser que se trate de um demiurgo:

um vidente, um médico, um carpinteiro de madeira,

ou um aedo divino, que com o seu canto nos deleita?

Estes homens são sempre convidados na terra ilimitada.

Agora um mendigo ninguém convidaria como despesa...

Na superfície, Eumeu diz a Antínoo que não foi ele, Eumeu, quem convidou o mendigo para usufruir da hospitalidade da casa de Odisseu, pois ninguém teria procedido assim. Para o receptor extradiegético e o próprio Cretense, porém, a formulação de Eumeu guarda outros sentidos. Como a quarta opção, a do aedo, é a única que recebe um verso inteiro, e Eumeu, de um lado, não presenciou o Cretense em atividades sucedâneas às de um carpinteiro ou médico e, de outro, não deu crédito à única "previsão" do Cretense, a de que Odisseu retornará, Eumeu parece obliquamente elogiar o mendigo como cantor. Exclusivamente para o receptor do poema, como críticos já notaram, as quatro atividades listadas por Eumeu se adequam a diferentes tarefas executadas por Odisseu ao longo da Odisseia. $^{42}$

\footnotetext{
${ }^{42}$ É possível supor-se que Eumeu sugira ao Cretense que, potencialmente, o considere um adivinho, médico, carpinteiro ou cantor (cf. Nagy, 1979, p. 233-234), essa última ocupação, pelo destaque conferido por ocupar um verso inteiro, sendo a opção que mais agrada a Eumeu (cf. Bertolini, 1988, p. 147). O verso 384, por sua vez, expressa funções que, na tradição indo-europeia, são assimiladas ao poeta (cf. Bertolini, op. cit.). O próprio Eumeu, ao criticar a habilidade narrativa dos estrangeiros que chegam em Ítaca e constroem histórias acerca de Odisseu, utiliza uma metáfora da carpintaria (Odisseia, XIV, 130-131). Sobre a relação poesia-carpintaria, inclusive no âmbito indo-europeu, cf. Bertolini, 1988, p. 153ss.; Schmitt, 1967, p. 298; West, 2007, p. 38-40. Cf. também Dougherty, 2001, p. 30-37, para quem o processo de Odisseu construir sua jangada sintetiza o modo como funciona a poesia oral (Calipso, como a Musa, fornece o material, mas ele tem o conhecimento). Ora, um dos momentos gloriosos de Odisseu na Odisseia é justamente a construção da jangada na ilha de Calipso. Vale notar que, em relação ao cavalo de pau, não se fala de Odisseu, na Odisseia, como seu construtor nem mesmo idealizador, mas como líder da tocaia (VIII, 492-495). Secundariamente, pode-se dizer que Odisseu aqui e ali assume as funções de médico e adivinho, de sorte que, para o receptor, a observação de Eumeu como que revelaria a identidade do estranho; cf. Krummen, 2008, p. 27-28.
} 
Nessa passagem, todavia, Eumeu menciona o "agradar, deleitar" (térpein) como o efeito da atividade de um bardo, sugerindo ao receptor que esse foi o efeito sobre ele das histórias que ouviu em sua cabana. Trata-se do mesmo verbo que Eumeu emprega no canto $\mathrm{XV}$ antes de começar a contar a história de sua vida, ou seja, a elaborar uma narrativa do tipo que, na Odisseia, em situações de hospitalidade, assemelha-se, pelo momento em que ocorre e pelo prazer que causa, aos cantos dos aedos (Odisseia, XV, 398-401):

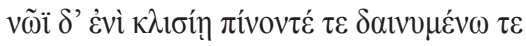

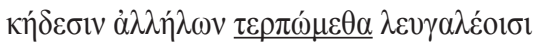

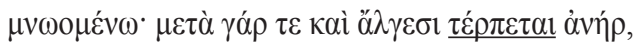

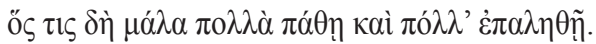

Nós dois ficaremos no casebre a comer e a beber

e a alegrarmo-nos com os sofrimentos um do outro, recordando-os: na verdade compraz-se com as suas dores o homem que muito tenha sofrido e vagueado. ${ }^{43}$

As notórias semelhanças entre a biografia do Cretense e a história de Eumeu (Odisseia, XV, 390-484), obviamente conhecida por Odisseu, também reforçam para o receptor que, assim como Homero é capaz de variar uma história com maestria, seu personagem principal também o é. Diante de Penélope, contudo, no canto XVII, Eumeu, significativamente, não fala mais de térpein mas de thélgein. ${ }^{44}$ Que a escolha de um ou outro verbo - e de outros termos de seus respectivos campos semânticos - seja relevante na Odisseia, isso me parece ter sido demonstrado por Pietro Pucci. ${ }^{45}$

O verbo thélgein é menos comum na Ilíada que na Odisseia, ${ }^{46}$ poema no qual se refere exclusivamente a deuses ou criaturas femininas (Calipso, Circe, Sirenas e Penélope). As exceções são Egisto, não exatamente notável pela sua virilidade, e os usos do verbo por Eumeu em relação ao Cretense, no canto XIV afirmando que seu hóspede não conseguiria

\footnotetext{
${ }^{43}$ Esses versos também indicam que a primeira história ouvida por Eumeu o deleitou.

${ }^{44}$ Ao invés da distinção semântica proposta por I. de Jong para os usos de thélgein entre, de um lado, "render inoperative (an organ), bewitch, put under a spell" e, de outro, "beguile, allure" (LfgrE, s.v. $\theta \dot{\lambda} \lambda \gamma \omega$ ), prefiro a definição de Steiner, 2010, p. 190: "this powerful verb describes the (usually temporary) alteration of a man's normal condition, thoughts and consciousness". Acerca de thélgein como termo poetológico na Odisseia, cf. Walsh, 1984, p. 14-15; Pucci, 1995, p. 193-196; Goldhill, 1991, p. 65-66; Pratt, 1993, p. 73; Halliwell, 2011, p. 47-52 e Peponi, 2012, p. 70-76. Acerca da técnica que pode ser atribuída a um aedo demonstrada pelo Cretense nas suas mentiras, cf. Kelly, 2008, p. 182-191 e Steiner, 2010, p. 21.

${ }^{45}$ Pucci, 1995, ao explorar a relação entre thélgein e o canto poético no poema, defende ser significativo que esse efeito não seja mencionado durante a performance de Demódoco no canto VIII, somente após a de Odisseu. Cf. Odisseia, XI, 333-334 (= XIII, 1-2) e Pucci, 1995, p. 191-215, 226-227.

${ }^{46} \mathrm{Na}$ Ilíada, exclusivamente para a ação de deuses, quando, especialmente no campo de batalha, tornam inoperantes um órgão e/ou uma capacidade humana.
} 
enfeitiçá-lo, e no canto XVII relatando a Penélope ter sido enfeitiçado pelo estrangeiro e que Penélope, ao ouvi-lo, também o seria. ${ }^{47}$

Circe enfeitiça por meio de drogas, ${ }^{48}$ mas Calipso, Penélope, Egisto e as Sirenas o fazem (ou tentam) por meio do discurso, no último caso, um discurso que também é canto (Odisseia, XII, 44). ${ }^{49}$ Trata-se, em todos esses casos, de um perigo a ser evitado. ${ }^{50}$ Paradoxal, nesse contexto, é também ser esse o efeito de uma performance poética bem sucedida. ${ }^{51}$

Daí a dúvida: Eumeu, quando fala do Cretense a Penélope, elogia o estranho de forma hiperbólica e incondicional ${ }^{52}$ ou a alerta acerca do perigo de se ouvir de forma acrítica a performance do Cretense? A sugestão de que o estranho deleita como um poeta, formulada diante dos pretendentes, é o primeiro momento de um elogio maximizado diante de Penélope ou serve de contraponto para o receptor, reforçando, para este, que Eumeu considera o Cretense, em última instância, uma figura opaca?

O peso dado por Eumeu, diante de Penélope, ao conhecimento que o Cretense tem de Odisseu (Odisseia, XVII, 522-523: "Diz que é há muito tempo amigo de família de Ulisses, / habitante de Creta, de onde é originária a raça de Minos") parece exagerado em comparação com o diálogo no canto XIV. Ele não precisa vendê-lo à rainha, pois o interesse partiu da própria Penélope. Parece-me, portanto, que o porqueiro, sabendo que a rainha vai querer ouvir o estranho de qualquer modo, insere em seu elogio um alerta discreto e ambíguo. $\mathrm{O}$ Cretense mostrou-se, até agora, digno de confiança, mas também um hábil manipulador de seu público. Ele nada falou de Odisseu aos pretendentes, o que, do ponto de vista de Eumeu, significa que está do lado de Telêmaco e do que esse representa. Independente de o retorno iminente de Odisseu ser ou não verdadeiro, ao não mencioná-lo aos pretendentes, o Cretense não os alerta.

No que diz respeito à poesia épica, ser um bom contador de histórias também implica determinada postura moral, e o Cretense deu mostras do seu valor não somente na cabana de Eumeu, mas também diante dos pretendentes, pois nada fala de Odisseu e

\footnotetext{
${ }^{47}$ Os deuses olímpicos que são sujeitos do verbo na Odisseia são Hermes, que usa sua vara para adormecer e guiar as almas ao Hades, e Atena e Zeus como possíveis aliados na batalha de Odisseu contra os pretendentes.

${ }^{48}$ Assim, embora não se use o verbo em conexão com Helena, o fato de ela manipular drogas (phármaka) na cena do banquete, no canto IV do poema, torna-a virtualmente capaz de thélgein (Odisseia, IV, 219-234).

${ }^{49}$ Os phármaka utilizados por Helena também (cf. nota anterior) estão associados a narrativas. No caso de Penélope, menciona-se que os pretendentes são enfeitiçados pelas suas palavras (Odisseia, XVIII, 281-283), mas também por érōs (v. 212-213), que, na cena em questão, diz igualmente respeito à toilette providenciada por Atena anteriormente; cf. Steiner, 2010, p. 199.

${ }^{50}$ Diante de Circe, Odisseu o consegue graças à ajuda de Hermes: Odisseu é akếlètos (Odisseia, X, 329).

${ }^{51}$ Cf. Odisseia, I, 337; em Odisseia, XI, 334, o substantivo refere-se à performance de Odisseu, que pode ser comparada àquela de um aedo; cf. supra n. 44.

${ }^{52}$ Para uma interpretação algo romântica dos efeitos do canto tal como descrito na poesia homérica, cf. Schadewaldt, 1965, p. 84-85.
} 
também não os bajula. Penélope indica que percebe o valor do estranho, pois, na resposta que dá a Eumeu, ao contrapor o desvalor dos pretendentes ao valor de Odisseu, indiretamente elogia o Cretense (Odisseia, XVII, 529-540) ${ }^{53}$ Eumeu não tem razão para criticar o Cretense a Penélope, mas um excesso de zelo embutido em seu elogio não parece estranho nesse poema nem em relação a essa personagem. Com isso, indiretamente, ele também lembra o receptor de que Penélope é uma importante ouvinte no poema e prepara o diálogo entre Odisseu e Penélope no canto XIX, um diálogo entre dois manipuladores de discursos capazes, ambos, de enfeitiçarem seus públicos, mas que também são ultracuidadosos com o que ouvem.

\section{Conclusão}

As passagens examinadas mostram que discrepâncias narrativas geradas a partir da performance discursiva de uma personagem podem ser explicadas a partir de duas ou mais camadas de sentido, internas e externas ao poema, compondo uma comunicação indireta e significativa entre o aedo e seus receptores, o que é particularmente eficaz em um poema no qual alguns sujeitos que executam performances de discursos também são representados como ouvintes atentos e perspicazes. A tematização do prazer causado pelas narrativas homéricas, portanto, envolve variáveis cognitivas diversas.

As três cenas de Eumeu também sinalizam um prazer paradoxal para o público da Odisseia ainda familiarizado com uma tradição épica oral produtiva: a de que de bom grado o receptor esquece outras versões do retorno de Odisseu sem se preocupar se alguma delas é mais verdadeira que aquela apresentada. Duas razões para isso se destacam: de um lado, o poeta é um excelente contador de histórias; de outro, o recorte moral segundo o qual os bons têm sucesso e os maus fracassam está de acordo com o nosso sentido ou desejo de justiça.

\section{REFERÊNCIAS}

AUERBACH, E. Mimesis. Dargestellte Wirklichkeit in der abendländischen Literatur. Bern: Francke, 1964.

AUERBACH, E. Mimesis. A representação da realidade na literatura ocidental. Tradução de George Bernard Sperber. São Paulo: Perspectiva, 1976.

AUERBACH, E. Mimesis. The representation of reality in Western literature. Translated by Willard R. Trask. Princeton: Princeton University Press, 2003.

AUSTIN, N. The function of digressions in the Iliad. Greek, Roman and Byzantine Studies, v. VII, p. 295-312, 1966.

\footnotetext{
${ }^{53}$ Esse juízo moral embutido parece ser a função principal de um discurso que Wilamowitz, 1927, considerou uma "ziemlich überflüssige Rede" que só tem a função de permitir o espirro de Telêmaco (p. 158-159). Harsh, 1950, p. 6, extrapola ao considerar que Penélope deve ficar admirada com a coincidência entre a presença do estranho e a previsão relatada por Teoclímeno recentemente.
} 
BAKKER, E. J. Pointing to the past. From formula to performance in Homeric poetics. Cambridge MA: Center of Hellenic Studies, 2005.

BAKKER, E. J. Homer, Odysseus and the narratology of performance. In: GRETHLEIN, J.; RENGAKOS, A. (org.). Narratology and interpretation. The content of narrative form in ancient literature. Berlin: de Gruyter, 2009, p. 117-36.

BAKKER, E. J. The meaning of meat and the structure of the Odyssey. Cambridge: Cambridge University Press, 2013.

BERTOLINI, F. Odisseo aedo, Omero carpentiere: Odissea 17.384-385. Lexis, v. II, p. 145164, 1988.

BLÜMLEIN, G. Die Trugreden des Odysseus. Frankfurt am Main: Rodenbusch, 1971.

BONIFAZI, A. Homer's versicolored fabric. Washington D. C.: Center for Hellenic Studies, 2012.

DANEK, G. Epos und Zitat. Studien zu den Quellen der Odyssee. Wien: Österreichischen Akademie der Wissenschaften, 1998.

DOUGHERTY, C. The raft of Odysseus. The ethnographic imagination of Homer's Odyssey. Oxford: Oxford University Press, 2001.

FINKELBERG, M. (org.). The Homeric encyclopedia. Malden: Wiley-Blackwell, 2011, 3 v.

FORD, A. Homer. The poetry of the past. Ithaca: Cornell University Press, 1992.

GOLDHILL, S. The poet's voice. Essays on poetics and Greek literature. Cambridge: Cambridge University Press, 1991.

HALLIWELL, S. Between ecstasy and truth. Interpretations of Greek poetics from Homer to Longinus. Oxford: Oxford University Press, 2011.

HOMERO. Odisseia. Tradução de F. Lourenço. São Paulo: Penguin; Companhia das Letras, 2011.

de JONG, I. J. F. A narratological commentary on the Odyssey. Cambridge: Cambridge University Press, 2001.

KELLY, A. Performance and rivalry: Homer, Odysseus, and Hesiod. In: REVERMANN, M.; WILSON, P. (org.). Performance, iconography, reception. Studies in honour of Oliver Taplin. Oxford: Oxford University Press, 2008, p. 177-203.

KRUMMEN, E. 'Jenen sang seine Lieder der ruhmvolle Sänger...’: Moderne Erzähltheorie und die Funktion der Sängerszenen in der Odyssee. Antike \& Abendland, v. LIV, p. 11-41, 2008. LEVANIOUK, O. A. Eve of the festival. Making myth in Odyssey 19. Washington D.C.: Center for Hellenic Studies, 2011.

LfgrE = SNELL, B.; MEIER-BRÜGGER, C. (org.). Lexikon des frühgriechischen Epos. Göttingen: Vandenhoeck \& Ruprecht, 1955-2010. 
LOUDEN, B. Eumaios and Alkinoos: the audience and the Odyssey. Phoenix, v. LI, p. 95-114, 1997.

LYNN-GEORGE, M. Epos. Word, narrative and the Iliad. London: MacMillan Press, 1988.

NAGY, G. The best of the Achaeans. Concepts of the hero in archaic Greek poetry. Baltimore: Johns Hopkins University Press, 1979.

OLSON, S. D. Blood and iron. Stories and storytelling in Homer's Odyssey. Leiden: Brill, 1995.

PEPONI, A.-E. Frontiers of pleasure. Models of aesthetic response in archaic and classical Greek thought. Oxford: Oxford University Press, 2012.

PORTER, J. I. Erich Auerbach and the Judaizing of philology. Critical Inquiry, Chicago, v. XXXV, p. 115-147, 2008.

PRATT, L. H. Lying and poetry from Homer to Pindar. Falsehood and deception in archaic Greek poetics. Ann Arbor: University of Michigan Press, 1993.

PUCCI, P. Odysseus polutropos. Intertextual readings in the Odyssey and the Iliad. Ithaca: Cornell University Press, 1995.

SCHADEWALDT, W. Von Homers Welt und Werk. Aufsätze und Auslegungen zur Homerischen Frage. 4. ed. Stuttgart: Köhler, 1965.

SCHEIN, S. An American Homer for the twentieth century. In: GRAZIOSI, B.; GREENWOOD, E. (org.). Homer in the twentieth century. between world literature and the western canon. Oxford: Oxford University Press, 2007, p. 268-285.

SCHMITT, R. Dichtung und Dichtersprache in Indogermanischer Zeit. Wiesbaden: Harrassowitz, 1967.

SCODEL, R. Listening to Homer. Tradition, narrative, and audience. Ann Arbor: University of Michigan Press, 2002.

SCODEL, R. The story-teller and his audience. In: FOWLER, R. (org.). The Cambridge companion to Homer. Cambridge: Cambridge University Press, 2004, p. 45-58.

SEGAL, C. Singers, heroes and gods in the Odyssey. Ithaca: Cornell University Press, 1994.

STANFORD, W. B. The Odyssey of Homer. 2. ed. London: Macmillan, 1965, 2 v.

STEINER, D. Homer. Odyssey, Books XVII and XVIII. Cambridge: Cambridge University Press, 2010.

STEINRÜCK, M. Rede und Kontext. Zum Verhältnis von Person und Erzähler in frühgriechischen Texten. Bonn: Rudolf Habelt, 1992.

VAN THIEL, H. Homeri Odyssea. Hildesheim: Olms, 1991.

WALSH, G. B. The varieties of enchantment. Early Greek views of the nature and function of poetry. Chapel Hill: University of North Carolina Press, 1984. 
WERNER, C. A ambiguidade do kleos na Odisséia. Letras Clássicas, v. V, p. 99-108, 2001.

WERNER, C. A liberdade restrita do aedo homérico. Linguasé Letras, v. VI, p. 171-182, 2005.

WERNER, C. Discrepâncias narrativas internas em Homero: Teoclímeno 'corrige' Telêmaco (Odisseia 15, 152-65). Phaos, v. 11, p. 83-104, 2013.

WERNER, C. Carpintaria de narrativas na Odisseia de Homero: Eumeu e o mendigo cretense. In: GALLE, H. (org.). Ficcionalidades: abordagens de um fenômeno literário e seus contextos históricos. São Paulo: Unesp, no prelo.

WEST, M. L. Indo-European poetry and myth. Oxford: Oxford University Press, 2007.

WHITMARSH, T. An I for an I: reading fictional autobiography. CentoPagine, v. III, p. 56-66, 2009.

WILAMOWITZ-MOELLENDORF, U. Die Heimkehr des Odysseus. Neue homerische Untersuchungen. Berlin: Weidmann, 1927. 